\title{
Types of Non-Equivalence in the Kĩkamba Bible Translation
}

\author{
Eunice N. Musyoka' ${ }^{1}$, Humphrey K. Ireri ${ }^{2}$ \\ ${ }^{1}$ Kigari Teacher Training College, Embu, Kenya \\ ${ }^{2}$ Faculty of Humanities and Social Sciences, Chuka University, Chuka, Kenya \\ Email: eunicemsyk@yahoo.com
}

How to cite this paper: Musyoka, E.N. and Ireri, H.K. (2019) Types of Non-Equivalence in the Kîkamba Bible Translation. Open Access Library Journal, 6: e5721.

https://doi.org/10.4236/oalib.1105721

Received: August 22, 2019

Accepted: September 26, 2019

Published: September 29, 2019

Copyright () 2019 by author(s) and Open Access Library Inc.

This work is licensed under the Creative Commons Attribution International License (CC BY 4.0).

http://creativecommons.org/licenses/by/4.0/

\begin{abstract}
This paper examines types of non-equivalences in the Kĩkamba Bible translation. Translation involves the rendering of a source text message into the target text so as to ensure that the surface meaning of the two is approximately similar and the structures of the source language are preserved as closely as possible in the target text. However, the process is hampered by non-equivalence, which occurs when a lexical item or an expression in the source language lacks an equivalent item to translate it into the target language. A descriptive research design was used to obtain information from a sampled population. The Bible is divided into two sections; the Old and the New Testament. It is further categorized into seven groups. Purposive sampling was used to select one book from each category and one chapter from each book to form the sample for the study. Data was collected through careful study of the English Revised Standard Version Bible to identify types of non-equivalences and the Kîkamba Bible to analyze how non-equivalence is handled. The study established two types of non-equivalences; non-equivalence at lexica level and above word level. The study reveals that non-equivalence is difficult to handle at lexical level mostly due to culture-specific words. Above the word level, translation is hampered by the use of figurative language in the source text. The study recommends that the translator needs a good background on the culture of the two languages and the metaphorical language use in the Bible. It is hoped that the research will be a contribution to applied linguistics in the area of translation, specifically on non-equivalence.
\end{abstract}

\section{Subject Areas}

Education, Linguistics

\section{Keywords}

Translation, Non-Equivalence, Source Text, Target Text, The Bible and 
Kĩkamba Language

\section{Topic One}

Here is the background to the study. Translation is defined as an art or craft which is concerned with replacing written message in one language by the same message in another language, which involves the process of encoding the meaning and forms in the target language (TL) after the translator has decoded or interpreted the meaning and forms of the source language (SL) [1]. It is also defined as the skill of understanding and interpreting the source text and rendering it in the target language by using the register, the background knowledge and other language resources to meet the intended purpose [2].

The translation of the Bible demands high skills and translators who have linguistic knowledge, social, cultural and communicative knowledge of the message of the source text [3]. The Bible translation does not only involve transfer of linguistic items from one language to another but also the transfer of style, emotions and impressions of the original text into the target language. This indicates that the translator needs to have adequate knowledge of both the source and the target language.

The origin of the church in East Africa is associated with the Christian missionaries who arrived at the coast in the mid $-19^{\text {th }}$ century. They were the first to make attempts to translate the Holy Scriptures into African languages [4]. He states that Kiswahili developed as a written language in Lamu, Mombasa and Zanzibar during the time of Islamic trade and settlement before the coming of Christianity, but the language was not versed enough for the purpose of translation. Christians, however, brought their Holy Book (the Bible) and started translating it into Kiswahili and other languages as well. A Kenyan theologian [5] made the following observation

the Bible is central to African Christianity, it is the most widely read book in the tropical Africa, the Bible is a widely available book in both urban and rural areas. It can be regarded as the most influential book in Africa [15] (p. 142).

This statement shows how important the Bible is to the Africans and therefore the need to make it available in a language they can understand. During this period descriptive study of language and of culture had not yet been done and therefore translation was seriously hampered by the two issues. The objective of the translator was to communicate the word of God as exactly as possible and this led to what is referred to as literal translation, which is referred to by different scholars in other terms, for example, semantic approach [6] and formal/ correspondence equivalence approach [7].

Translation is always unfinished work and any new translation calls for revision and gradually for another translation as the language adapts and changes to meet the needs of evolving cultures and traditions of the society [7]. A number 
of problems are encountered in trying to define a theory of translation, the process is more complicated due to the fact that translating depends on a theory of language that includes all classes of texts, audience and circumstances of use.

Krapf was the pioneer in translating the scriptures into Kĩkamba which was the second oldest translation of scriptures in Kenyan languages after Kiswahili. The first translation was the gospel according to St. Mark by Krapf in 1850. Hoffman, Pfitzinge and Ernest Brutzer of the Leipzing mission translated the gospel according to St. Luke in 1898, the book of the Acts of the Apostles in 1904 and the gospel according to St. Mathew 1909. In these books the Kîkamba used was rather difficult for the native speaker to understand because it was inconsistent. A team of translators led by Geoge W. Rhoad retranslated the gospel according to St. Mark in 1915, the gospel according to St. John 1916 and the book of Daniel in 1935. They were assisted by Aaron Kasyoki and Jeremiah Kyeva who played the role of native informants, [4]. Later in 1956 the Kîkamba Bible in a consistent Kîkamba language was completed by a team of the African Inland Missionaries (A I M) assisted by the nationals and published as "Maandîko Matheu Ma Ngai Metewa Mbivilia Nĩmo Ũtiano wa Tena na Mweư”, (Holy Scripture of God Called the Bible is the Old and the New Covenant). It was published by the British Foreign Bible Society, (BFBS) [8].

Translation of the Bible was as a result of a lot of cooperation and collaboration on the part of the Christian missionaries. The input of the native speakers was kept at a minimum which possibly explains the reason why the socio-linguistic and in particular the dialectal situation of Ũkambanĩ was not taken into account for example other dialect speakers were ignored and preference was given to Masakũ speakers [4]. Problems of unnaturalness, lack of clarity or even ungrammaticality, in the 1956 Kîkamba Bible are not only due to the literal approach adopted by the translators but also reflects the translator's linguistic incompetence as a non-native speaker.

A recent Kîkamba Bible version which used the standardized Kîkamba was translated by a team of translators and published by the Bible Society of Kenya in 2011. A later edition was done by Mbiti who translated the New Testament directly from Greek and was launched in Kĩtui in 2015. He asserted that he did this edition single handedly due to the challenges he used to face while using the former edition. The Kîkamba Bible version 2011 is more readable by the native speakers since it was translated by a team and therefore, reducing subjectivity.

One major problem in translating the Bible is the culture since all languages reflect culture of which they are part of. Culture is complex, while language consists of only verbal and non-verbal symbols, culture includes all kinds of beliefs [9]. The subject material of the Bible covers a wide range of cultural situations. Languages possess different syntactic and morphological features that pose many translation difficulties resulting from lack of equivalents at morphological, lexical and syntactic levels. This results in linguistic and cultural non-equivalence. In the religious culture the problems are often concerned with terms that are re- 
ligious-specific for example the names of the deity which leads to cultural or situational non-equivalence. Language is part of the society's culture and the problems experienced are due to the special characteristics of the languages involved in the translation.

The problems of equivalence and adaptation between languages are greatest in the lexical items. The area of meaning of a word in one language is never completely identical with the area of meaning of a similar word [10]. More problems are experienced in combination of words with specialized meanings. The translator needs knowledge of the actual usage of the item in that language. Apart from the cultural issues, languages are spoken with variations that result from geographical, social, education, gender and age among other factors. Kîkamba has varieties such as Machakos and Kĩtui dialects that are spoken in Machakos and Makueni counties respectively, and a translator needs to use the standardized dialect; one used in written documents such as in literature books and in the Kîkamba dictionary consistently to avoid confusion.

Kîkamba is spoken with different variations largely due to geographical reasons. Four dialects are distinguished [11]; the Machakos dialect, the Makuenĩ dialect, the Kĩtui North dialect and Kĩtui Central dialect. The dialects are named after the area they are spoken. According to him, Machakos dialect also known as Kĩmasakũ dialect is the one used in important written works like the Kĩkamba literature for example story books such as [12] and [13] and also in instructional materials for lower primary classes. This study on types of non-equivalence used the standardized dialect.

Difficulties in translating are majorly posed by the concept of non-equivalence, where the TT is in short of a word or an expression that is used in the ST to convey the message. This is a problem that is evident in all the levels starting from the word level up to the textual level. For example, at word level non-equivalence may originate from culture bound words, at grammatical level they may occur where a grammatical aspect such as gender, number or tense does not exist in the target language. It is also evident in the textual level in terms of cohesion and coherence. Apart from grammatical meaning in a text there is also pragmatic meaning which calls for pragmatic equivalence [14]. The translator needs to work out what is written (word conceptual meaning) and also what is implied in order to arrive at a quality translation. This paper discusses the types of non-equivalence in Kîkamba Bible at lexical/word and above the word level.

The role of the translator is to encode meaning and forms of the source language into the target language. Equivalence is aimed at so that the texts can be compared in terms of meaning. Equivalence in this context is defined as the similarity between the ST and the TT at word or above the word level. The translator faces different challenges in trying to achieve the equivalence in all these levels. Proponents of the equivalence-based theory define equivalence as the relationship between source text (ST) and target text (TT) that allows the TT to be considered as the translation of the ST [15]. This means that the two texts can be 
compared in terms of meaning. The researcher used the Revised Standard Version Bible [16] as a working source text and the Kîkamba Bible [17] to determine cases of non-equivalence and how they are handled in the process of translation. The RSV 2008 Bible was used because the team that translated the Kîkamba Bible 2011 mainly used it as main source text. The researcher also made reference to New International version and New King James Version, among others.

\section{Subtopic A}

Here is more background to the study on equivalence and non-equivalence. For the translated text to be considered as the translation of the original there must be equivalence. The role of the translator is to replace the language of the ST with the language of the TT, [18] and the implicit focus in all translation definition is upon the concept of equivalence. Translation can be defined as reproducing in the receptor language the closest natural equivalent of the source language message first in terms of meaning and secondly in terms of style [19]. In the Bible translation the emphasis is given on the meaning since the Bible is not written for entertainment but to communicate to the receptor audience.

The lack of equivalence is what is defined as non-equivalence. Equivalence can be achieved in a number of ways. For example, referential or denotative equivalence in which the SL and TL words supposedly refer to the same thing in the real world and connotative equivalence, where the SL and TL words trigger the same or similar associates in the minds of the native speakers in the two languages [19]. He further suggested text-normative equivalence where the SL and TL words are used in the same or similar contexts in their respective language and also pragmatic equivalence also referred to as dynamic equivalence [9] in which the SL and TL words have the same effect in their respective languages. He also defined formal equivalence where SL and TL words have similar orthographic or phonological features.

The comparative analysis of the study of ST and TT one should discuss the degree of translation equivalence in the two texts. The terms formal correspondence and textual equivalence are identified in translation [20] while the concept of equivalence can be extended to cover similarity in ST and TT devices in the respective texts [14]. She uses the term textual equivalence to refer to both formal correspondence and textual equivalence.

The main goal of translation is to achieve equivalent effect or dynamic equivalence. The principle of equivalent effect refers to equivalence in the literal meaning of words and equivalent in the association or emotions that words bring in the mind of the reader, [7]. The translator needs to come up with good plans (strategies) to achieve this effect. This paper explores the types of non-equivalence and also determines the translation strategies used to handle them.

\section{Topic Two}

Here the text on methodology. The study was guided by the principles of de- 
scriptive research design. A descriptive research design falls under qualitative research approach. The researcher used the qualitative research approach which seeks to investigate the natural setting and the results are presented in form of descriptive essays and not in statistics, [21].

The Bible has 66 books and is divided into two sections the Old Testament and New Testament. The Old Testament has 39 books and the New Testament has 27 books. The books are further divided into other categories. For the purpose of this study the researcher adopted a religious classification by the Revised Standard Version Bible [16] which put the Bible books into seven categories; Pentateuch, Historical books, Poetical books, Prophetic books, Gospel, The early church, and the Epistles. The researcher selected one book from each category which included: Genesis, Judges, Song of Solomon, Isaiah, Mathew, Acts of the Apostle and Hebrews. The researcher further purposively sampled the first chapter of each book for the research except the book of Mathew and Hebrew in which the last chapter was sampled. A total of seven chapters formed the sample for the study.

The process involved reading the selected chapters from each book intensively using the Revised Standard Version [16] to explore the types of non-equivalences using the Equivalence theory [9]. The verses that reflected cases of non-equivalence were highlighted and recorded. The texts were categorized according to the type of non-equivalence. Equivalence can appear at word, grammatical, textual, and pragmatic levels [14]. The non-equivalence in this paper was analyzed at lexi$\mathrm{cal} /$ word level and above the word level. The process also involved reading of the Kîkamba Bible [17] to determine whether non-equivalence was successfully handled or not leading to successful or unsuccessful transfer.

\section{Topic Three}

Here is the text on the discussions of the research. The data analysis involves identification and explanation of non-equivalence in translating the Bible into Kîkamba. The researcher was also engaged in evaluating the translation strategies to determine whether the message of the source text was successfully transferred in the TT or not. The source language is English and the target language is Kîkamba. The researcher categorized non-equivalence in this study into two broad categories, that is, lexical/word level non-equivalence and above word level non-equivalence. The non-equivalence above the word level is discussed under figurative use of language. Non-equivalences identified are presented in Table 1.

The successful transfer is used in this case to refer to the translation of the full

Table 1. Types of Non-equivalence in the Kîkamba Bible Translation.

\begin{tabular}{cccc}
\hline Type of non-equivalence & Number of identified texts & Successful transfer & Unsuccessful transfer \\
\hline Lexical/word & 41 & 16 & 25 \\
Figurative language & 17 & 6 & 11 \\
\hline
\end{tabular}


message or the meaning of the ST to the TT while unsuccessful transfer refers to partial translation (or mistranslation in some cases) of the ST message or meaning in the TT. These two broad categories on the types of non-equivalences identified in the Kîkamba Bible translation are discussed under lexical/word and above the word level.

\section{Topic Four}

Here is the text on lexical/word non-equivalence. A word is defined as the smallest unit of language which is expected to possess individual meaning [14]. $\mathrm{He}$ argues that in translation everything would be easier if there were a one-to-one relationship between words and meaning in the source and the target language. Five types of non-equivalence at word/lexical level were identified; culture-specific words, words that are lexicalized in the target language but do not share the same semantic field or meaning (differ in sense), words whose concept exist in the TL but do not have a one-word equivalent, words with two senses in the context of the source text and the use of archaic terms in the source language.

\subsection{Subtopic A}

Here is the text on culture-Specific words. The identified words were: heaven, scarlet, crimson, silver, angel, prince, sepulchre, tomb, chariots, vineyard, gold, oak, myrrh, and henna. Out of the fourteen words identified from the sampled texts only five were successfully transferred in the TT, to achieve the goal of translating, while the rest of the words (nine) were not correctly translated into the TT. Each word is analyzed and the strategy used to translate it is identified to determine the success or lack of it in rendering the meaning in the TT.

For example the word "heaven" in Genesis 1:1 is a concept that is lexicalized in the Christian dialect which is associated with Hebrew culture. The Akamba god did not create "heaven". In Genesis 1:1 the word "heaven" is substituted with "cloud" which resulted to ambiguity since the word refers to both the "clouds" and "heaven". It is also used in Isaiah 1:2, and Acts 1:11 in which it is translated as matunĩ (clouds). The receptor reader can however interpret the word correctly from the context. This substitution through cultural filtering strategy is successful since the ambiguity can be sorted out from the context.

In Isaiah 1:18, the words scarlet and crimson are used in two different similes to highlight on the intensity of the sins that are committed by the Israelites, the writer uses colors for comparison. Scarlet is a word that is not lexicalized in Kîkamba and is not included in the Kîkamba dictionary [22], and therefore it is the red color that exists in the TT language, using the expression "ndune mũno" (excessively red) achieves the goal of translation. The lexical item "crimson" is substituted by "nthakame" which means blood which is also red in color. Substitution through cultural filtering achieves the goal of translation.

The concept "silver" Isaiah 1:22 is rendered through naturalization. The translator only changed the spelling but retained a similar sound of the SL pro- 
nunciation in the TL. "Silver" represents wealth since money is made of silver and among the Akamba coins are referred to as "sillinva". It is also used in Isaiah 1:22 and translated in the same way achieving the goal of translation. The word "angel" is reflected in Mathew 28:2 translated as "malaîka". This word is borrowed from Kiswahili and achieves the goal of translation since it is a loan word that is commonly used and accepted in the standard Kîkamba, [22].

The concept "gold" which is used in the book of Song of Solomon 1:11 does not exist in Kîkamba and therefore the translator used the technique of borrowing in order to relay it in the TT. The word "thaavu" is borrowed from Kiswahili, the strategy of naturalization was used after borrowing to make the concept fit in the TT. This achieves the goal of translating "thaavi" is treated as a valuable commodity in Kĩkamba just as gold.

The leadership vocabulary "princes" as used in Isaiah 1:23 is not lexicalized in Kîkamba since the society"s leadership is not organized and ruled through royal families. "Princes" are sons in a royal family who may not be leaders or kings and therefore the use of "atongoi" (leaders) to substitute it does not transfer the meaning of the concept thus the message is not fully conveyed.

In Mathew 28:1 and Mathew 28:8 the words "sepulchre" and "tomb" are used respectively and both are not lexicalised in Kîkamba because people are buried in graves among the Akamba. The words are translated as "mbũa" (graves) through cultural filtering strategy which does not meet the goal of translating since the two concepts are different.

The word "Hail" in Mathew 1:9 is a loan word from Hebrew, it was interpreted and translated as "mũuo nĩwethĩwe nenyu" (peace be with you) achieving the semantic meaning but the implicature was not transferred to the TT. The word "chariots" used in Song of Solomon 1:9 is a culture specific term that is not lexicalized in Kîkamba and the translator used cultural adaptation and substituted it with what is commonly found among the targeted community, "makasya" (carts). The concepts are different semantically and therefore the intended message is not rendered correctly in the TT.

The concept "vineyard" as used in Song of Solomon 1:6, 14, Isaiah 1:8, and in all of them the concept is translated as "mũunnda wa mĩsavivî" (garden of grapes). The descriptive strategy defines what it is, although, the target reader may not readily comprehend the care given to a vineyard or even the importance or value of the graves in the original (Hebrew) culture from which the image is drawn. The culture filtering strategy therefore does not fully transfer the meaning of the ST into the TT.

A number of trees that grow in the environment or among the community from which the Bible was written caused some translation problems in this category. For example the use of oak, myrrh and henna. The "oak" tree does not exist among the targeted readers and is translated as "myalonî" as seen in Isaiah $1: 29$, which makes it difficult to comprehend the meaning in the context, because the word is not common in the lexis and it is not included in the Kîkamba 
dictionary [22]. The "myrrh" which also does not grow in Ũkambanĩ, was translated through explicitation and borrowing as reflected in Song of Solomon 1:13. The borrowing strategy from Kiswahili of the concept "manemane" is not successful in transferring the concept. The use of the "henna" tree in Song of Solomon 1:14 which also does not grow in Ũkambani resulted to unsuccessful translation since the concept "ina" is not lexicalized properly in the TT language.

The culture-specific words named objects or concepts that are not found among the targeted audience and the concepts used to translate them were either borrowed or domesticated to fit in the culture. Near equivalents for example for colors were used and achieved the goal of translation while the use of cultural filtering in the majority of the cases did not achieve the goal of translating.

\subsection{Subtopic B}

Here is the text on words lexicalized in the target text language but differ in sense. Seven words were identified in this category which includes: governor, city, springs, upper room, white ropes, wine and Sabbath. None of these words were rendered correctly in the TT. These words are discussed in the following texts.

The words "governor" and "city" were not successfully rendered in the TT as illustrated in Mathew 28:14 and Isaiah 1:8, 21, 26. Governor is translated as "ngavana" changing the spellings but retaining a close English pronunciation, a strategy referred to as naturalization. This kind of leadership position did not exist in Ũkambanĩ until 2010 [23] when a new constitution was introduced. The Governor's power in the ST may not be comparable to that of the governor in the TT but the introduction of the County government under the leadership of the governor is a contribution towards understanding the term. The terms are not used in the same context in both the TT and the ST language, this naturalization strategy did not fully transfer the concept in the ST. The word "city" is substituted with the word "village" through cultural filtering which does not achieve the goal of translation.

Since they do not share the same semantic meaning, some words in this category had an element of ambiguity in the TT, that is, the word would represent two meanings in the TT, for instance the use of "springs" in Judges 1:15, the expression "springs of water" was translated as "ithima" which means "wells" [22]. The two words are different in meaning and they also have different connotation meaning in the Bible [24]. Another example of a concept that exists in the target language but has a different sense, is "upper room" as used in the book of Acts 1:13. It is rendered as "flat". The use of the cultural filtering and literal translation did not fully translate the concept in the TT. The translation of "white ropes" in the book of Acts 1:10 resulted to ambiguity in the TT since it was rendered as "white clothes". The concept exists in Kîkamba but it is not used in the same sense and context of use is not the same as used in the source text language. The word "sabath" is used in the Bible to refer to the day the Jews set aside to worship as indicated in Mosaic laws [24]. It is used in Mathew 28:1, and 
rendered in the target text through naturalization, as "savato". The translator in this case does not achieve the goal of translation since among the target audience it refers to Saturday worship. The people in the targeted community worshipped in different days and refer to the days differently.

The word "wine" used in Song of Solomon 1:4 is lexicalized in the TT language but the two-share different semantic fields. In the Bible "wine" has a connotation meaning which is not easy to translate in the TT. The translator borrowed a term from Kiswahili, "ndivai" which is closely related to the meaning in ST language but it is a distance word in the TT language. The borrowing strategy was not successful in this case.

The translation of words that do not share the same semantic fields or words that showed non-equivalence at the sense level posed challenges to the translators leading to partial transfer of the meaning/message of the ST into the TT.

\subsection{Subtopic C}

Here is the text on words without a one-word equivalent. The third category of non-equivalence at the lexical level is of words whose concept exists in the TL but do not have a one-word equivalent. The researcher identified eleven words in this category; camp, inhabitant, fragrant, fatherless, widow, lambs, spy, brethren, thumbs, toes and mare. All the words except "mare", "fatherless" and "brethren" were rendered successfully in the TT, as discussed in the following texts.

The word "camp" in Hebrews 13:11, 13 is translated as a place where people were settled.

The Akamba people who form the majority of the targeted readers do not live in camps and therefore there is no one-word equivalent of the term but the descriptive approach successfully transferred the meaning of the ST to the TT. The descriptive strategy to translate the word "inhabitants" as used in Acts 1:19 and Judges 1:27 successfully render the message of the ST into the TT. It is also reflected in the use of the word fragrant in Song of Solomon 1:3, 11 in which the word is described making it clear to the reader of the TT.

The concept "fatherless" is lexicalized in the target language but there is no one word equivalent to refer to it. The translator used addition and the general term "ndĩwa" which accommodates children without a father or/and mother as reflected in Isaiah 1:17 and thus it is not successful. The word "widow" in the same verse was successfully translated through explicitation and description strategies as "mũndũ mũka ndĩwa" (a woman whose husband died). The concept "lambs" in Isaiah 1:11, was successfully rendered into the TT through descriptive strategy as "tũtena twa malondûu" (the young ones of a sheep) and "spy" in Judges 1:23 is elaborated as "andũ kwa kĩmbithî" (people in secret) who were send to find out how the people of Bethel lived. In this elaboration the message of the ST is communicated in the TT. There are cases where the concepts in this category needed some expansion, for example, the use of "thumb" and "toes" in 
Judges 1:6 which were also described successfully in the TT as "syaa ila nene sya moko" (the big fingers of the hands) and "syaa ila nene sya maũü" (the big toes of the feet) respectively.

The word "brethren" as used in the Bible in Mathew 28:10 refers to both men and women-people belonging to a given faith or fellowship [24] but is rendered as "ana-a asa" (step brothers) which distorts the intended meaning of the ST since it excludes women in the TT. The word "mare" is substituted with the general word (superordinate) "mbalasi" (horse) which includes both the female and the male horse as seen in Song of Solomon 1:9. The translation is not successful since it lacks equivalence as far as sense is concerned.

The lexical items in this category as displayed in the discussions were rendered successfully in the target text using the descriptive equivalent strategy except three concepts, that is "fatherless", "brethren" and "mare."

\subsection{Subtopic D}

Here is the text on words with two senses in the source text context. The forth category composed of words that had two meanings or senses in the source text context and thus resulted to a problem of deciding on the sense to transfer to the TT. In this study it is referred to as contextual ambiguity. Six words were identified in this category: sanctuary, maiden, chambers, couch, hospitality and stranger. None of them was rendered correctly in the TT.

The term "sanctuary" in Hebrews 13:11 was rendered as "vandũ vatheu mũno" (clean/holy place) through description and generalization. The meaning here does not just refer to a place and thus it leads to mistranslation. The word "maiden" in Song of Solomon 1:3 was translated as "eittü" (girls) which is unsuccessful since a "maiden" in the Bible is specifically used to refer to an elderly married or unmarried woman who is a virgin in this specific context [24]. The word "chambers" may refer to a private room or a bed room as used in Song of Solomon 1:4 but through cultural filtering it is rendered as "tũsumbanĩ twa nthĩnî" (small inside houses) which does not communicate the meaning of the source language. In the Song of Solomon 1:7 the word "flock" which is a superordinate word to include large number of animals has been translated to mean "ndîthya ya mbũi na malondu" (sheep and goats) only in the TT but it also includes big animals like cows. The "flock" or the "sheep" in the Bible connotatively refers to the people who have accepted God to be their shepherd [24] but when the goats are included the specification leads to mistranslation. The word "couch" used in the book of Song of Solomon 1:12 would best be described as a comfortable sofa or luxurious seat, but it was substituted with the word "kitanda" (bed) which is commonly used among the targeted readers and thus unsuccessful in rendering the message of the ST into the TT.

In the book of Hebrew 13:2 the word "hospitality" was translated as "mũithokya" (welcoming) which is a general word but "hospitality" in this context means to 
welcome with some positive concern/caution. Kîkamba is limited in terms of synonyms. The two words are related but are different in meaning. The word "strangers" was translated as "aeni" (visitors) which implies guests. A stranger would imply someone who is unfamiliar to the host or a foreigner in this context, and showing hospitality to such is not the norm in target community, this led to mistranslation.

\subsection{Subtopic E}

Here is the text on archaic words in the source language. The last category was non-equivalence due to odd or old-fashioned terms in the ST. Only two concepts were identified in this category and they were successfully rendered in the TT. These were the words "raiment" and "ass." The word "raiment" used in Mathew 28:3 is an archaic term for clothes and therefore the translator used the modern term "ngũa" (clothes) to domesticate it through cultural filtering, achieving the goal of translation. The word "ass" in Isaiah 1:3 is an old-fashioned term, out of vocabulary but it is translated as "ing oi" (donkey) which is the modern word used in describing the concept referred to. The substitution through cultural filtering strategy is successful in both cases.

Table 2 can be used to summarize equivalence at the lexical/word level.

From this discussion it can be concluded that words that share different semantic fields and words with two meanings in the ST context were the most difficult to translate. This difference is caused by the fact that the STL and TTL belong to different cultures. Culture-specific words also posed a challenge but the translator tried to domesticate them to the TT with some little success. Words which did not have a one-word equivalent (whose concept exist in the TT) were rendered in the TT using the descriptive equivalent strategy which was quite successful except in a few cases.

\section{Topic Five}

Here the text on non-equivalence above the word level. Non-equivalence above the word may be due to figurative use of language or the grammatical system of

Table 2. Lexical/word Non-equivalence in the Kîkamba Bible Translation.

\begin{tabular}{cccc}
\hline $\begin{array}{c}\text { Type of } \\
\text { non-equivalence }\end{array}$ & $\begin{array}{c}\text { Number of items } \\
\text { identified }\end{array}$ & Successful transfer & Unsuccessful transfer \\
\hline A & 14 & 5 & 9 \\
B & 7 & 8 & 3 \\
C & 11 & 0 & 6 \\
D & 6 & 2 & 0 \\
E & 2 & 2 & 6 \\
\hline
\end{tabular}

The A, B, C, D and E used in the table represent the following: A-Culture-specific words; B-Words lexicalized in the target language but differ in sense; $\mathrm{C}-$ Words without one-word equivalence; $\mathrm{D}-$ Words with two senses in the source text context; E-Archaic words in the source language. 
the language. This paper concentrated on the figurative use of the language. Non-equivalence was witnessed in cases where language was used in a figurative manner. It is argued that "languages are not nomenclatures and the concepts of one language may differ radically from those of another, since each language articulates or organizes the world differently and languages do not simply name categories; they articulate their own" [25]. The figures of style such as idioms, metaphors and similes along with other morphological, syntactic and lexical components create a certain stylistic quality and distorting it in the TT can lead to mistranslation. The translator has to strive to get systemic equivalents [26]. In this paper the researcher concentrated on the use of metaphors and similes (Table 3).

It is evident from the data that the figurative use of language caused challenges to the translator, each case is discussed separately in the following subtopics.

\subsection{Subtopic A}

Here is the text on metaphors. Non-equivalence at the level of the metaphor is experienced because metaphors express comparison in one way or another, [27]. It is argued that a metaphor does not have the anomalous meaning but it is a form or a way of indirect communication [28] which means that the translator should interpret it first. The metaphor in the TT will therefore be the translator's version of the expression in the ST. If the metaphor is misinterpreted by the translator then the target audience will get the wrong meaning. The texts are identified as non-equivalence (NE) in the analysis.

An example of a metaphor is demonstrated in Song of Solomon 1:13-14 in the following text;

NE: 1

ST: My beloved is to me a bag of myrrh that is between my breasts.

TT: Mwendwe wakwa kwakwa nĩ ta kamũvuko ka mauta me mũuke mũseo matewa manemane, kailiñlwe katĩ wa nondo syakwa.

B/T: My love to me is like a bag of oil of good smell called manemane placed in between my breast.

In Song of Solomon 1:13 the metaphor was translated through the use of a simile using the unit change strategy and literal approach to retain the implied meaning but "myrrh" is omitted and other additions are made. The challenge is that the lexical word myrrh is not lexicalized in Kîkamba. The tree does not grow in Ũkambanĩ and therefore difficult to interpret the metaphor because the image of the tree is expected to create a mental picture in the mind of the receptor

Table 3. Types of non-equivalence at the Figurative use of Language.

\begin{tabular}{cccc}
\hline $\begin{array}{c}\text { Type of Figurative } \\
\text { Language use }\end{array}$ & $\begin{array}{c}\text { Number of items } \\
\text { identified }\end{array}$ & Successful Transfer & Unsuccessful Transfer \\
\hline Metaphors & 5 & 6 & 5 \\
Similes & 12 & 6 \\
\hline
\end{tabular}


language reader. This mental picture is replaced with oil with a good smell. A descriptive approach has been used to quantify the term with some additional information. Reduction strategy was also used to reduce the metaphor to a simile. Clarity is still lacking because the word "manemane" is borrowed from Kiswahili and is not lexicalized in Kĩkamba. Although the basic semantic implied meaning that the speaker adores the beloved is transferred to the TT, the comparison which renders the intensity of adoration is lost and thus the transfer is considered unsuccessful.

The metaphor in Song of Solomon 1:14 is also not fully transferred in the TT due to challenges of the image "henna" which is not lexicalized in Kĩkamba.

NE: 2

ST: My beloved is to me a cluster of henna blossom in the vineyards of En-gedi.

TT: mwendwe wakwa kwakwa nĩ ta Malaa me mũuke mũseo ma mũtĩ wa kwĩyanakavya wĩtawa ina me mũũndanĩ wa mĩsavivũ wa Eni-ngeti.

B/T: my love to me is like flowers with good smell of tree of making oneself beautiful called ina in the garden of grapes of En-gedi.

In verse Isaiah 1:14 the speaker compares the beloved with "henna" which is a word borrowed from Arabic which is used to make dye that is used to color hair or tattoos [29]. This is therefore a loan word in English and does not have an equivalent in Kîkamba. The translator reduced the metaphor to a simile to translate it into the receptor language, the tree was transliterated using different letters but retaining the sound it had in the source language, (ina) and also by adding information to include the fact that the tree is used for beautifying oneself. The words "cluster" and "blossoms" are not rendered in the TT. Reducing the metaphor into a simile results to reducing its "force" among the TT audience, the other challenge was the word "vineyard" which was translated as "garden of grapes" but a vineyard has the element of trees that are grown for beauty or for ornamental purposes, a place for outdoor activities [29] which fits well in this context. The care given to the "vineyard" is not communicated in the TT. The image creates a different picture to receptors of the TT from the one it created in the minds of the receptors of the ST which is a crucial principle in dynamic equivalence [7]. So in this case the content is not fully transferred in the TT.

The use of "anointing oils" in Song of Solomon 1:3 resulted to a case of non-equivalence since in the target domain the intensity of the meaning of the expression is not realized since there is no oil that is used for anointing and people are actually not anointed or honored using oil.

NE: 3

ST: your anointing oils are fragrant.

TT: mauta maku menyunga nesa.

$\mathrm{B} / \mathrm{T}$ : your oil is smelling nicely.

The translator used a paraphrase changing the metaphor to a statement which resulted to ambiguity since the comparison of anointing oil and the fragrance is lost. 
There is a challenge of non-equivalence due to the structural use of the elements in the figurative language. For example, in Song of Solomon 1:3 the metaphor is literally translated leading to mismatch in translation.

NE: 4

ST: your name is oil poured out;

TT: na ĩsyĩtwa yangu nĩ ta mauta me mũũke mũseo monosye,

B/T: and your name is like oil with good smell poured.

The translator used a simile to translate the metaphor literally. The two have the same idea but a metaphor is more intense in terms of meaning than a simile which is an open comparison. Some theologians and philosophers of religion believe that the nature of a religious truth is such that it can only be conveyed metaphorically, and therefore there is need for the translator to come up with appropriate principles for interpreting religious texts in the source language metaphorically and not literally or word for word in order to transfer the same meaning and effect into the TT [30].

Due to non-equivalence of the specific images used in the metaphors the translator's challenge was how to create the same images in the TT, for example in Song of Solomon 1:15.

NE: 5

ST: your eyes are doves.

TT: metho maku nĩ mauu ta ma Ĩvũ̃.

$\mathrm{B} / \mathrm{T}$ : your eyes are peaceful like the ones for a dove.

The metaphor is reduced to a simile. The image is reduced to just one quality of a dove that of being humble. The implicature in the metaphor in the ST is substituted by an explicature in the TT. This narrows the meaning that is implied in the target language.

From the discussion it can be concluded that metaphors are quite difficult to translate. The translator may partially transfer the message of the ST to the TT but the intensity or the "punch" of the message and the "touch" is lost in the process of translation.

\subsection{Subtopic B}

Here is the text on similes. A simile is a figure of speech used in language in general both in formal and informal, it is a direct comparison that uses a comparison marker [31]. Similes are used in the Bible to communicate similarity vividly.

For example in the book of Isaiah 1:8 a simile is used as illustrated below;

NE: 6

ST: And the daughter of Zion is left like a booth in a vineyard,

TT: Ndũa ya Saioni îtiĩtwe ĩilyi ta, kĩvanda kĩ mũũndanĩ wa mĩsavivũ.

B/T: The village of "Saioni" is left looking like, a section/place in the garden of grapes.

The simile has been translated using a simile in which the image "daughter" has been replaced with a "village" which is implied in the ST but not explicitly 
brought out. The expression "the daughters of Zion" according to the translator represents the location which is compared with portion (booth in the ST) of a garden with grapes (vineyard in the ST). By changing the image to adapt to the TT the translator distorted the meaning of a "booth" and the "vineyard". In terms of size the booth is made to be small and the vineyard which is translated as a "garden" is more valuable than just a garden. The "daughter of Zion" is narrowed down to a place which is one possible interpretation and thus reducing the implicature.

The second simile was translated literally in the TT. The image "a lodge" is substituted with "a small house in the garden".

NE: 7

ST: And the daughter of Zion is left like a lodge in a cucumber field,

TT: Ndũa ya Saioni îtiittwe îilyi ta, ta kasumba ke mũũndanĩ wa mongũ.

B/T: village of Saioni is left looking like, like a small house in the garden of butter nuts.

Cucumber is grown in Ũkambanĩ and therefore has been literally translated. The attachment that religious culture has with cucumbers seems to be special, a highly regarded food among the Hebrews from whose culture the Bible draws its relevance. This can be referred in the Bible during their journey to Egypt, they cried to Moses when they were faced with famine and remembered the cucumbers that they were eating in Egypt as seen in the book of Numbers 11. The targeted audience is majorly the Akamba people who also have a special attachment towards "cucumber" as witnessed in their folklore, for examples in riddles and stories. Similes are either literal or non-literal [32] and therefore the literal translation meets the goal of translation.

The third simile was literally translated word-for-word and the message of the source text was relayed in the target text as illustrated below:

NE: 8

ST: And the daughter of Zion is left like a besieged city.

TT: Ndũa ya Saioni îtiîtwe îilyi, ta ndũa îthyũlülũkĩtwe nĩ amaitha.

B/T: village of "Saioni" is left looking like village surrounded by enemies.

The "city" is domesticated as "village". The core message, the idea that it is surrounded by the enemies whether a city or a village is conveyed.

A simile has a vehicle and a topic. The vehicle is the entity to which the topic is compared accompanied by a comparison marker and the similarity features are the properties shared by the topic and the vehicle, [33]. The markers result to different syntactic requirements as seen in Isaiah 1:9 where the nouns of the places are used implicitly. For the translator to convey the equivalent content there is need for a translation strategy.

NE: 9

ST: we should have been like Sodom, and become like Gomor'rah.

TT: twĩthĩwa twathelile ta ndũa ya Sondomu na ta ndũa ya Ngomolo.

B/T: we would be finished like the village of Sodom, And like the village of 
Gomor'rah.

In the simile the source text author claims that if a few of the people in this context were not spared then their end would have been like that of Sodom and Gomor' rah. The end of Sodom and Gomor'rah is implied and the reader can only connect the simile with the story in the Bible where both were utterly destroyed because the people who lived in them were continually sinning against God. These images created a gap because the translator did not make use of amplification strategy for clarity or foot note. The literal translation therefore remains a mystery until the receptor audience draws the comparison of the Bible story in Genesis chapter 18.

Non-equivalence is also enhanced by the fact that similes serve different purposes, for example, they establish a link with the reader's general knowledge [34]. The readers targeted by the TT do not share the same general knowledge. This knowledge makes it easier to understand and readers also use it to reveal and interpret abstract or unfamiliar concepts by using the concepts in the context that are known to them for example in Isaiah 1:18, a number of similes have been used and in each case the reader needs general knowledge to understand the similes.

NE: 10

ST: though your sins are like scarlet, they shall be as white as snow.

TT: ona vala naĩ syenyu nĩ ndune mũno, mũkathew' a mwĩthĩwe mwĩ eũ ta ĩa.

B/T: although your sins are very red you will be made white like Snow.

In the first simile the image "scarlet" has been substituted with red color and added the adverb of degree (very), the word is relevant and it is used to help the reader create an image of how badly these people have sinned against God by using the color. The scarlet color is contrasted with the white color in this context. A simile helps the reader to interpret the abstract or unknown concept from the concrete or the known concept [33]. The color "scarlet" was a challenge to the translator in Kîkamba because it is not lexicalized in Kîkamba. The image in the other part of the simile is literally translated. "Snow" is not common in the community of the targeted audience but it is not a distance term and comparing it white with it enhances interpretation. The simile is also abstract in Kîkamba in that sins are compared with color but the fact that red color is associated with evil in the targeted community makes it less abstract, making the message comprehensible.

In the second one sin is compared with crimson, which is also an abstract idea.

NE: 11

ST: though they are red like crimson, they shall become like wool.

TT: o na vala nĩ ndune ta nthakame, mũkeeũvw' a ta wia wa ĩlondu.

B/T: even though they are red like blood you will be made white like the wool of sheep.

In this simile the word "crimson" was substituted with "red as blood" and in 
other part of the same simile the white color is compared with wool. Sheep in Ũkambanĩ is not generally white they are not ideally kept for wool since they are a local breed that is purposely for meat. This led to ambiguity in the TT and loss of the concrete object used in the ST.

Some similes used images of real or concrete objects that did not readily exist in TT, as illustrated in Isaiah 1:30 the "oak" tree is not commonly grown in Ũkambanĩ or its value is not known in the targeted community. Its value and nature contribute to its meaning in the context and the comparison in the simile.

NE: 12

ST: For you shall be like oak whose leaf withers.

TT: Nîkwĩthĩwa mũkeethĩwa mũilyĩ ta mũtĩ wa mwalonĩ ũvovetye matũ.

B/T: for you will be like a tree of mwalonI with withered leaves.

In this text the "city of Zion" is liken to the "oak" which is a tree known for its hard wood and typically grown in England and America [29]. The leaves of the "oak" in this simile are said to wither, and this happens when a tree is not blossoming. The name used to translate the oak tree is uncommon among the Akamba community and does not even exist in the Kîkamba dictionary [22]. The comparison is not clear leading to unsuccessful translation. The second simile in Isaiah 1:30 was fully rendered using a simile.

NE: 13

ST: For you shall be like a garden without water.

TT: mũillyĩ ta mũũnda ute kĩw' ũ.

$\mathrm{B} / \mathrm{T}$ : you shall be like a garden without water.

In this second simile "Zion" is liken to garden that does not have water which can be interpreted as unproductive garden since water is an essential component for a garden to look green and produce. The translator literally translated the simile as it was to the target text through the use of word for word strategy. Since the image is clear the translator has achieved the goal of translating.

Similes are used in a specific structure and form especially in poetic literature. Since languages have different structures of expressing meaning, the structural equivalence is a challenge in translating similes that appear to be tied to the form. In the Song of Solomon 1:5 two similes are used which are structured parallel to each other.

NE: 14

ST: am comely like the tents of Kedar,

TT: nĩ mũmbe nesa ta maeema ma Ketali.

B/T: am created beautiful like tents of Ketali.

The image in the simile is a "tent made of kedar" which is an abstract concept or place in the mind of the targeted audience and thus the message of the ST is not clearly rendered in the TT. The translator used naturalization to translate the image "Kedar", which did not make the image concrete but the core message that the beloved is beautiful is communicated but the intensity of the beauty is not relayed in the TT and the comparison is not clear. 
The other simile used "curtains of Solomon" as the image to show how beautifully the daughters of Zion are created. The reader can only comprehend the meaning of the image by relating it to the story of King Solomon in the Bible.

NE: 15

ST: am comely like the curtains of Solomon.

TT: nĩ mũmbe nesa ta vasia îla syĩ kwa Solomon.

B/T: am beautiful like the curtains that are there at Solomon's.

The message would be made easier to comprehend by providing some communication cues in the TT.

The fact that, similes also have aesthetic function, that is, to talk about something in a creative way, poses a challenge of equivalence in the TT. They generally communicate concisely and efficiently, [33]. The aesthetic is coupled with the formatting of the similes in a text. This formatting is changed in the TT and thus the aesthetic function is either not realized or realized in a different way.

The figurative use of language at the simile level caused challenges to the translator because some of the images used to unearth the meaning of the abstract terms were not lexicalized in Kîkamba. Some that were lexicalized did not have the same extended or connotation meaning as in the ST and hence did not have the element of the same equivalent effect for both the ST audience and TT audience. Of the identified twelve similes, six were rendered successfully in the target text while six were not.

\section{Topic 6}

Here is the text on conclusion. The study concludes that cultural issues in the lexical items caused challenges in the translation, for example, words that share different senses and words with two meanings in the ST context were the most difficult to translate. Words which did not have a one-word equivalent but the concepts exist in the target language were easily rendered successfully in the TT using the descriptive equivalent strategy. The researcher also concludes that the aesthetic beauty in the figurative use of the language is untranslatable. The metaphors and similes in the source text have a different effect on the target text. The form/structure that adds to the meaning and the aesthetic function is lost in translating figurative language. The study therefore concludes that translation of non-equivalence texts is possible but the source text is "devoured" and a "hybrid" text is created which carries the message of the original text but in its own version.

\section{Conflicts of Interest}

The authors declare no conflicts of interest regarding the publication of this paper.

\section{References}

[1] Newmark, P. (1988) A Textbook of Translation. Prentice Hall, Hertfordshire. 
[2] Kelly, H.C. (2000) The Bible in the Twenty First Century. American Bible Society, New York.

[3] Coulson, S. (2000) Semantic Leaps: Frames Shifting and Conceptual Blending in Meaning Constructions. Cambridge University Press, New York, Cambridge. https://doi.org/10.1017/CBO9780511551352

[4] Majola, A.O. (1999) God Speaks in Our Own Languages-Bible Translation in East Africa. 1844-1998. Bible Societies, Nairobi.

[5] Mugambi, J.N.K. (1995) From Liberation to Reconstruction: African Christian Theology after the Cold War. East African Educational Publishers.

[6] Newmark, P. (1991) About Translation. Multilingual Matters, Hertfordshire.

[7] Nida, E.A. and Taber, C.R (1982) The Theory and Practice Translation. E.J. Brill, Leiden.

[8] Waruta, D.W. (1975) Scripture Translation in Kenya. University of Nairobi, Nairobi.

[9] Nida, E.A. (1964) Towards a Science of Translating. Brill, Leiden.

[10] Ciampa, R.E. (2011) In the Wisdom of the Cross: Exploring 1st Corinthians. Nothignam.

[11] Maundu, P. (1980) Reconstruction of Kikamba Consonantal Sounds. University of Nairobi, Nairobi.

[12] Ngotho, T.M. (1963) Kimena Kya Nzou na Mbiti (the Enmity Between the Elephant and the Goat. EALB.

[13] Kimilu, D.N. (2013) Mukaamba Wa Wo 2nd ed. Kenya Literature Bureau, Nairobi.

[14] Baker, M. (1992) In Other Words; A Course Book on Translation. Routledge, London.

[15] Toury, G. (1995) Descriptive Translation Studies and Beyond. John Benjamin, Amsterdam. https://doi.org/10.1075/btl.4

[16] (2008) Revised Standard Version Bible. BFBS, London.

[17] Mbivilia ũvoo Mũseo Kĩkamba kya ĩvinda Yĩ̃ (2011) Nairobi: Bible Society of Kenya.

[18] Brisset, A. (2000) The Search for a Native Language: Translation and Cultural Identity. The Translation Studies Reader, 343-375.

[19] Kollar, W. (1989) Equivalence in Translation Theory in Chesterman A Reading in Translation Theory. Oyfinn Lecute Ab, Finland.

[20] Catford, J.C. (1965) A Linguistic Theory of Translation. Oxford University Press, London.

[21] Dingwall, R. (1998) Quality in Qualitative Research. Journal of Health Services Research \& Policy, 3, 167-172. https://doi.org/10.1177/135581969800300308

[22] Mwau, J. (2006) Kikamba Dictionary. Regal Printing Ltd., Nairobi.

[23] Statistics, K.N.B.O. (2010) The 2009 Kenya Population and Housing Census (Vol. 1). Kenya National Bureau of Statistics.

[24] Douglas, J. and Tenny, M. (1987) The New International Dictionary of the Bible Grand Rapids. Zondervan Publishing House, Zonderva.

[25] Collision-Burch, C. (2007) Paraphrasing and Translation. Routledge, New York.

[26] Kvetko, P. (2009) An Introduction to Translation Studies: A Practical. University SV, Trava. 
[27] Lycan, W.G. (2000) Philosophy of Language. Routledge, London.

[28] Davidson, D. (1978) What Metaphors Mean in Inns. University of Chicago Press, Chicago, IL.

[29] (2010) Oxford Advanced Learners Dictionary of Current English. 8th Edition.

[30] Blumenberg, H. (1960) Paradigmen zu einer Metaphorologie. Bouvier and Co., Bonn.

[31] Pilrainen, E. (2007) Figurative Phraseology and Culture. In: Granger, S. and Meunie, F., Eds., Phraseology. An Interdisciplinary Perspective, John Benjamins Publishing Company, Amsterdam. https://doi.org/10.1075/z.139.20pii

[32] Bredin, H. (1998) Comparison and Similes. Lingua, 105, 67-78. https://doi.org/10.1016/S0024-3841(97)00030-2

[33] Fromilague, C. (1995) Figures and Styles. Nathan, Paris.

[34] Gutt, E.A. (2000) Translation and Relevance: Cognition and Context. Blackwell, Oxford. 